\title{
The composition of the cetacean community in the Falkland (Malvinas) Islands, southwest South Atlantic Ocean
}

\author{
Composición de la comunidad de cetáceos alrededor de las islas Malvinas, Océano Atlántico sudoccidental
}

\section{Helen Otley $^{1 *}$}

\begin{abstract}
${ }^{1}$ Environmental Planning Department, Falkland Islands Government, Stanley, Falkland Islands, FIQ 1ZZ, United Kingdom *Currently West Coast Tai Poutini Conservancy, Department of Conservation, Hokitika 7810, New Zealand. heleno@southcom.com.au
\end{abstract}

\begin{abstract}
Resumen.- La evaluación de los registros de varamientos para las islas Falkland (Malvinas) desde 1866 y hasta septiembre 2012 confirma que la comunidad de cetáceos alrededor de esas islas está compuesta de 7 especies de ballenas, 7 ballenas picudas, el cachalote, 8 de delfines y 1 de marsopa. El registro de varamientos corresponde con la diversidad de especies a partir de observaciones en el mar, pero confirma también la presencia de algunas especies muy poco frecuentes, que no se acercan generalmente a embarcaciones y/o que corresponde a especies de aguas profundas. El calderón de aleta larga, el delfín austral, la tonina overa, el delfín cruzado y el cachalote son consideradas especies que tienen una presencia regular alrededor de las islas. Seis especies son consideradas escasas, 11 raras y se tiene registros históricos de 2 especies que, sin embargo, no han sido registradas en tiempos recientes. Los varamientos sugieren potenciales cambios temporales para algunas especies, reflejando posiblemente recuperaciones post-explotación, cambios en las condiciones oceanográficas de la región y/o en la disponibilidad de presas.
\end{abstract}

Palabras clave: Ballena, delfín, varamientos, Sudamérica, aguas subantárticas

Abstract.- An evaluation of the stranding record for the period 1866 to September 2012 confirms that the Falkland (Malvinas) Islands cetacean community is composed of 7 species of baleen whale, 7 beaked whale species, sperm whale, 8 species of dolphin and 1 of porpoise. The stranding record supports the species composition based on at-sea surveys, but also confirms the presence of some rare, vessel-shy and/or offshore and deepwater species. Five species - long-finned pilot whale, Peale's dolphin, Commerson's dolphin, hourglass dolphin and sperm whale - are considered to have a regular presence in the Islands. Six species are considered infrequent, 11 are considered rare and 2 species had a historic presence but have not been recorded in recent years. The stranding record suggests potential temporal changes for some of these species, reflecting perhaps a recovery of their population from over-exploitation and/or changes in oceanographic conditions and/or prey availability.

Key words: Whale, dolphin, strandings, South America, subantarctic waters

\section{INTRODUCTION}

Although the distribution of most cetacean species has been described, these are mostly reported by reference to oceanographic regions and the seasonal presence and abundance is not well detailed. Cetacean distribution and abundance has been determined for most species via ad hoc sightings and surveys, dedicated surveys, remote recording devices and stranding records. Stranding records, if collated over 5-10 years across a coastline longer than $10 \mathrm{~km}$, often reflect a greater species richness than live animal surveys, particularly in documenting cryptic species, extra-limital records for more common species and revealing changes in mortality or distribution due to oceanographic conditions (Palacios et al. 2004, Norman et al. 2004, Aragones et al. 2010, Danil et al. 2010, Pyenson 2010).
In the southwest South Atlantic Ocean, around 20-30 species of cetacean are known to occur (Bastida et al. 2007, Reeves et al. 2002). A comprehensive 33-year long stranding record for Tierra del Fuego reveals species never or only very irregularly sighted in that region (Goodall et al. 2008a). Due to the geographic location and oceanographic conditions, the cetacean community in the southwest South Atlantic Ocean includes species that migrate through seasonally, sub-Antarctic species that range circumpolar as well as endemic species.

The Falkland (Malvinas) Islands (52 $30^{\circ} \mathrm{S}, 60^{\circ} 00^{\prime} \mathrm{W}$ ) are situated approximately $460 \mathrm{~km}$ off the east coast of South America, on a projection of the Patagonian continental shelf. The diversity of bathymetry and oceanographic 
features around this island archipelago provides an abundance of different habitats suitable for a multitude of cetaceans. Cetacean books, natural history books of the Falkland (Malvinas) Islands, survey reports, scientific publications and websites provide details of the cetacean community, but sometimes, the data behind this information is unclear (Fraser 1950, Hamilton 1952, Strange 1992, White et al. 2002, Turner 1880, Baker 2001, Woods \& Woods 2006, McCarthy \& Unwin 2007, Yates \& Brickle 2007, Otley et al. 2011).

A 3 year seabird and marine mammal survey was conducted in Falkland (Malvinas) Islands waters by White et al. (2002), and they described cetacean species as being 'regular' (species with more than 10 sighting records totaling more than 200 animals), 'scarce' (those with more than 10 sighting records of less than 200 animals) and 'rare' (less than 10 sightings). Four species of cetaceans, the long-finned pilot whale (Globicephala mela Traill, 1809), hourglass dolphin (Lagenorhynchus cruciger Quoy and Gaimard, 1824), Peale’s dolphin (Lagenorhynchus australis Peale, 1848) and Commerson's dolphin (Cephalorhynchus commersonii Lacépède, 1804) were considered regular species in the waters of the Falkland (Malvinas) Islands. Five species, fin whale (Balaenoptera physalus Linnaeus, 1758), sei whale (B. borealis Lesson, 1828), minke whale (species not identified), sperm whale (Physeter macrocephalus Linnaeus, 1758) and southern bottlenose whale (Hyperoodon planifrons Flower, 1882) were considered scarce and 5 - southern right whale (Eubalaena australis Desmoulins, 1822), humpback whale (Megaptera novaeangliae Borowski, 1781), killer whale (Orcinus orca Linnaeus, 1758), southern right whale dolphin (Lissodelphis peronii Lacepede, 1804) and Mesoplodon beaked whales were considered rare. A further 4 species are considered as part of the Falkland (Malvinas) Islands cetacean community but have been recorded rarely. These are the pygmy right whale (Caperea marginata Gray, 1846), dusky dolphin (Lagenorhynchus obscurus Gray, 1828), spectacled porpoise (Phocoena dioptrica Lahille, 1912) and bottlenose dolphin (Tursiops truncatus Montagu, 1821) (Hamilton 1941, 1952, Strange 1992).

Stranding records for the Falkland (Malvinas) Islands have not been assembled in a comprehensive manner, yet cetacean strandings are detected regularly, probably because the cool climate preserves dead animals for a considerable time. In this work, we describe the cetacean diversity of the Falkland (Malvinas) Islands using the collected records of stranded specimens from the late 1800s to September 2012 and sighting data is used to give a complete overall picture of the cetacean community.

\section{MATERIALS AND METHODS}

Records of dolphins and whales stranded in the Falkland (Malvinas) Islands between 1866 to September 2012 were compiled in detail from a variety of sources, including records held by the British Museum of Natural History, the Falkland Islands Museum, scientific publications, local newspapers and newsletters. However, for the most part, records were elicited verbally by speaking to local naturalists, landowners and people who had traveled at sea and by land and air around the Falkland (Malvinas) Islands. Species identification used verbal and written reports, photographs taken in situ at the time of stranding or discovery of the specimen and examination of any archived material was carried out by local naturalists and cetacean scientists based in the Falkland (Malvinas) Islands, Argentina, Chile, United Kingdom, Australia and New Zealand.

For each stranding event, the key data obtained where possible was stranding location, date of discovery, species and method of species identification. The stranding date was determined by the date of discovery and the degree of decomposition of the carcass. A month/ year date could be assigned for many records but a decade date (e.g., 1980, 1990s) had to be assigned to some records that were only weathered bones or memories.

For some of the strandings, the exact location on the island was not documented. In order not to exclude these stranding events, location information has been presented in categories of distance of the island or the coastline for East Falkland Island and West Falkland Island to the 200 $m$ water depth contour, which is considered to be the edge of the continental shelf. The categories used were:

(i) within $30 \mathrm{~km}$ of water $200 \mathrm{~m}$ deep, being the islands in the southwestern part of the archipelago, which are for the most part steep cliffs and erosional shores facing the prevailing northerly flowing Falklands (Malvinas) Current;

(ii) being between 30 and $60 \mathrm{~km}$ from water $200 \mathrm{~m}$ deep, being the southeastern and eastern Lafonia region, which generally has shallow beaches;

(iii) on Patagonian Shelf waters (i.e., more than $60 \mathrm{~km}$ from water $200 \mathrm{~m}$ deep), which is the northeastern, northern and northwestern sectors. As this part of the archipelago is for the most part in the lee of the Falklands (Malvinas) Current, the coastlines tend to be depositional rather than erosional (Fig. 1). 


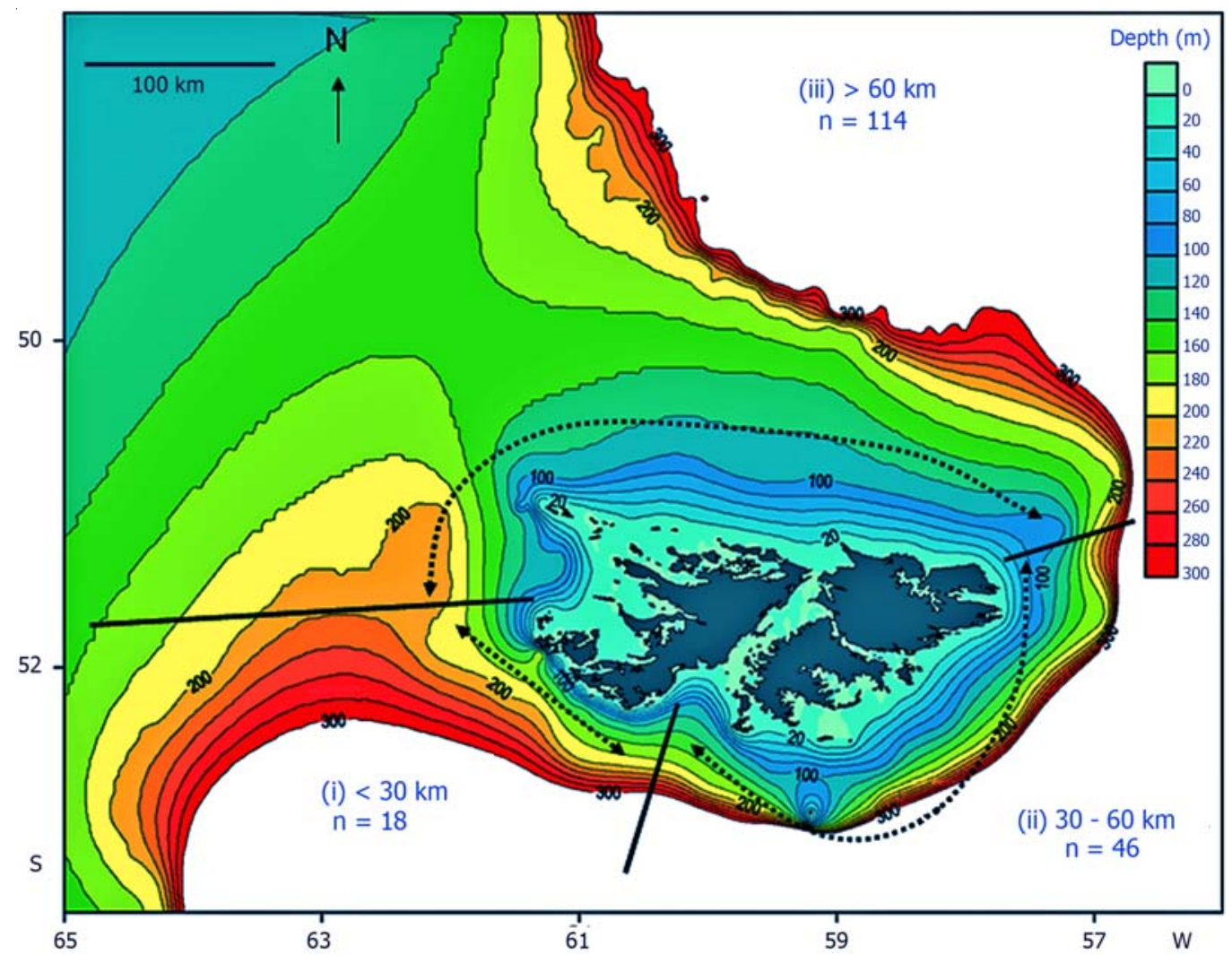

Figure 1. The number of cetacean stranding events on coasts (i) within $30 \mathrm{~km}$ of the shelf break, (ii) between 30 and $60 \mathrm{~km}$ from the shelf break and (iii) on the Patagonian Shelf in the Falkland (Malvinas) Islands between 1866 and 2012 / Número de varamientos de cetáceos en las costas (i) dentro de los $30 \mathrm{~km}$ del quiebre de la plataforma, (ii) entre 30 y $60 \mathrm{~km}$ desde el quiebre de la plataforma y (iii) en la Plataforma Patagónica alrededor de las islas Falkland (Malvinas) entre 1866 y 2012

Based on the stranding and at-sea sighting data, the frequency of species presence has been described following the definitions used by White et al. (2002), but for the purpose of improved clarity the rank of scarce has been changed to 'infrequent'.

\section{RESULTS}

A total of 201 cetacean stranding events representing 24 species were collected for the period 1866 to September 2012 (Table 1). Apart from long-finned pilot whale, bottlenose dolphin and sperm whale (and possibly Andrew's beaked whale, see Otley et al. 2011), all other species were single strandings. Although few specimens were found whole and fresh, none of these animals showed any obvious injuries that would have been inflicted by, for example, ship collisions or fishing nets. Eighty-four percent of the stranding events were toothed whales. The 4 most frequently stranded species were longfinned pilot whale, sperm whale, strap-toothed whale (Mesoplodon layardii Gray, 1865) and Commerson's dolphin.

There was no specific location information for $11 \%$ of the 201 stranding records (Table 1). Nearly $60 \%$ of the total records were at locations adjacent to the Patagonian Shelf (i.e., more than $60 \mathrm{~km}$ from the shelf break) and only $9 \%$ were at islands located no more than $30 \mathrm{~km}$ from the edge of the continental shelf (i.e., waters deeper than 200 m) (Fig. 1).

\section{BALEEN WHALES}

Three species of large baleen whale were recorded for the Falkland (Malvinas) Islands - blue whale (B. musculus Linnaeus, 1758), sei whale and fin whale (White et al. 
Table 1. Number of cetacean stranding events for each 24 species/species group in the Falkland (Malvinas) Islands between 1866 and 2012 / Número de varamientos para cada una de las 24 especies o grupos de especies alrededor de las islas Falkland (Malvinas) entre 1866 y 2012

\begin{tabular}{|c|c|c|c|c|c|c|}
\hline \multirow{2}{*}{ Common name } & \multirow{2}{*}{ Scientific name } & \multirow{2}{*}{$\begin{array}{l}\mathrm{N}^{\circ} \text { of cetacean } \\
\text { stranding events }\end{array}$} & \multicolumn{4}{|c|}{ Distance of standing location to $200 \mathrm{~m}$ water depth } \\
\hline & & & $>30 \mathrm{~km}$ & $30-60 \mathrm{~km}$ & $<60 \mathrm{~km}$ & Not known \\
\hline Long-finned pilot whale & Globicephala mela & 71 & 9 & 7 & 54 & 1 \\
\hline Large baleen whales & & 23 & 2 & 8 & 12 & 1 \\
\hline Blue whale & Balaenoptera musculus & & & & & \\
\hline Sei whale & B. borealis & & & & & \\
\hline Fin whale & B. physalus & & & & & \\
\hline Sperm whale & Physeter macrocephalus & 21 & 2 & 4 & 13 & 2 \\
\hline Strap-toothed whale & Mesoplodon layardii & 11 & 0 & 4 & 5 & 2 \\
\hline Commerson's dolphin & Cephalorhynchus commersonii & 9 & 0 & 2 & 5 & 2 \\
\hline Peale's dolphin & Lagenorhynchus australis & 7 & 1 & 0 & 3 & 3 \\
\hline Southern bottlenose whale & Hyperoodon planifrons & 5 & 0 & 3 & 2 & 0 \\
\hline Arnoux's beaked whale & Berardius arnuxii & 4 & 0 & 0 & 3 & 1 \\
\hline Cuvier's beaked whale & Ziphius cavirostris & 4 & 0 & 1 & 3 & 0 \\
\hline Dusky dolphin & Lagenorhynchus obscurus & 4 & 0 & 1 & 0 & 3 \\
\hline Gray's beaked whale & Mesoplodon grayi & 4 & 1 & 2 & 1 & 0 \\
\hline Killer whale & Orcinus orca & 4 & 0 & 0 & 2 & 2 \\
\hline Minke whale & Balaenoptera sp. & 4 & 0 & 4 & 0 & 0 \\
\hline Hector's beaked whale & Mesoplodon hectori & 4 & 0 & 3 & 1 & 0 \\
\hline Southern right whale & Eubalaena australis & 4 & 1 & 0 & 1 & 2 \\
\hline Spectacled porpoise & Phocoena dioptrica & 4 & 0 & 0 & 2 & 2 \\
\hline Andrew's beaked whale & Mesoplodon bowdoini & 3 & 0 & 1 & 0 & 2 \\
\hline Beaked whale sp. & & 3 & 1 & 2 & 0 & 0 \\
\hline Bottlenose dolphin & Tursiops truncatus & 3 & 0 & 1 & 2 & 0 \\
\hline Mesodoplon sp. & Mesodoplon sp. & 3 & 0 & 0 & 3 & 0 \\
\hline Hourglass dolphin & Lagenorhynchus cruciger & 2 & 1 & 1 & 0 & 0 \\
\hline Southern right whale dolphin & Lissodelphis peronii & 2 & 0 & 2 & 0 & 0 \\
\hline Humpback whale & Megaptera novaeangliae & 1 & 0 & 1 & 0 & 0 \\
\hline Pygmy right whale & Caperea marginata & 1 & 0 & 0 & 1 & 0 \\
\hline Total & & 201 & 18 & 46 & 114 & 23 \\
\hline
\end{tabular}

2002). There were 23 strandings of large baleen whales. Although some animals were identified locally to species level, there were few photos and skeleton material available for whale experts to confirm species identification. Of the 9 records where the observer provided identification to species level, only two records were identified by local Falkland Islanders as blue whale, one record from the period 1930s/1940s and one record in 1962. However, for both records, the species identification could not be confirmed.
Due to the inability to identify with confidence large baleen specimens to species level, strandings of this type have been assembled together. The vast majority of the large baleen whale strandings occurred on coastlines on the Patagonian Shelf, with only 2 records at islands that were within $30 \mathrm{~km}$ of the shelf break (Table 1). The frequency of stranding was highest during the most recent decade (2000-2009) (Fig. 2). The month of stranding was known for 8 of the 9 strandings that occurred between 2000 and 2009. These strandings all occurred between January and May, with 4 events in March and April. 


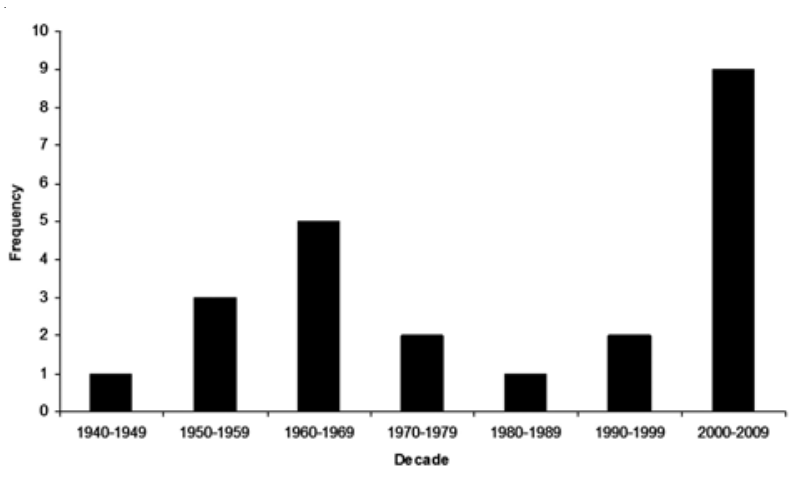

Figure 2. Frequency of large baleen whale strandings in the Falkland (Malvinas) Islands in each decade between 1940 and 2009 / Frecuencia de ballenas varadas en las islas Falkland (Malvinas) en cada década entre 1940 y 2009

One large baleen whale found dead ashore in 1959 had a scientific harpoon embedded in it. Although the harpoon was sent by the farm manager to the farming company's UK office, the International Whaling Commission does not hold any records of harpoons found in whales stranded ashore in the Falkland (Malvinas) Islands (A. Cherry, pers. comm. ${ }^{1}$ ), nor is such a record included in comprehensive reports of tagging studies of blue whale and sei whale (Branch et al. 2007, Brown 1978, respectively).

For smaller baleen whale, there were 4 records of southern right whale strandings, ranging from 1879 to 1990, 4 records of minke whale (not distinguished to species) from the period 1992-2003, one record of a pygmy right whale from the 1940s/1950s and one record of a stranded humpback whale in 1984.

\section{SPERM WHALE}

The sperm whale was the third most frequent species recorded stranded, with 21 stranding events scattered across the archipelago. More than half of the sperm whale strandings occurred on coastlines on the Patagonian Shelf, with only 2 records at islands that were within 30 $\mathrm{km}$ of the shelf break (Table 1). Strandings were reported from 1898 to 2012, with no peaks during any particular decade. Seventeen records were single strandings and 5 were mass strandings with 3, 5, 10 and 2 pods of 18 animals each. For only 5 records was the gender of the stranded whale(s) recorded, and these whales were all males, including one group of 18 males.

\section{BEAKED WHALES}

Thirty-eight records of stranded beaked whales were documented for the period 1866 to 2010 in the Falkland (Malvinas) Islands and these involved at least 7 species in 4 genera, (Otley et al. 2011). In January 2011, a Mesoplodon species of beaked whale was found dead in shallow water but the specimen was not secured ashore. Based on the available photographs, it was likely to be a sub-adult strap-toothed whale, Hector's beaked whale (M. hectori Gray, 1871) or Gray's beaked whale (M. grayi van Haast, 1876) (A. van Helden, pers. comm. ${ }^{2}$ ). In March 2011, a complete skeleton of a $310 \mathrm{~cm}$ long Hector's beaked whale was found; a comparison of the available photos indicated that it was not the same individual as found in January. The Hector's beaked whale was physically subadult. In February 2012, the partial skeleton of a sexually mature male strap-toothed whale was found.

Thus to date, the strap-toothed whale is the most common beaked whale species found stranded in the Falkland (Malvinas) Islands with 11 records, including 2 neonates. Andrew's beaked whale (M. bowdoini Andrews, 1908), Arnoux's beaked whale (Berardius arnuxii Duvernoy, 1851), Cuvier's beaked whale (Ziphius cavirostris Gray, 1823), Gray's beaked whale (M. grayi van Haast, 1876), Hector's beaked whale and southern bottlenose whale were recorded on between 3 and 5 occasions (Table 1). Seven of the 41 beaked whale records did not have any location information. Nearly half of the strandings occurred on coastlines on the Patagonian Shelf, with only 2 records from an island located within $30 \mathrm{~km}$ of the shelf break (Table 1).

\section{DoLPHINS}

There were 4 records of killer whale being stranded in the Falkland (Malvinas) Islands. These all occurred in the southeast sector of the archipelago (which is $30-60 \mathrm{~km}$ from the shelf break), including one stranding on Sea Lion Island ( $\left.52^{\circ} 26^{\prime} \mathrm{S}, 59^{\circ} 05^{\prime} \mathrm{W}\right)$, where pinnipeds breed, and 3 strandings at beaches where pinnipeds do not breed. One record was in 1986 and the others between 1996 and 1997. Two of the animals were first found apparently unwell/stranded in shallow waters and both were dragged to deeper waters but later found washed ashore dead within $24 \mathrm{~h}$ of the attempted rescue.

The long-finned pilot whale was the most frequently stranded species, with 71 records from 1866 to 2011. There

${ }^{1}$ International Whaling Commission, Cambridge

${ }^{2}$ National Museum of New Zealand 'Te Papa Tongarewa', Wellington 
are also 35 pilot whale skulls at BMNH that were deposited from the Falkland (Malvinas) Islands by J. Hamilton during 1947 to 1949 . There is no information about where and when these skulls were obtained (R. Sabin, pers. comm. ${ }^{3}$ ). There are 3 documented stranding events for the 1930s 1940s period, which may be some of the skulls collected by J. Hamilton. However, these 35 skulls have not been included in the stranding record because it is not clear whether they represent one or multiple events.

Fifty-four of the long-finned pilot whale stranding records (76\%) occurred at locations on the Patagonian Shelf (Table 1). When weathered skulls were found, the date of the stranding was not always clear. However, the year of stranding could be determined for all stranding events from 1984 onwards ( $\mathrm{n}=43$ events). In most years since 1984, at least one pod of long-finned pilot whale has stranded, with a peak of 10 separate stranding events

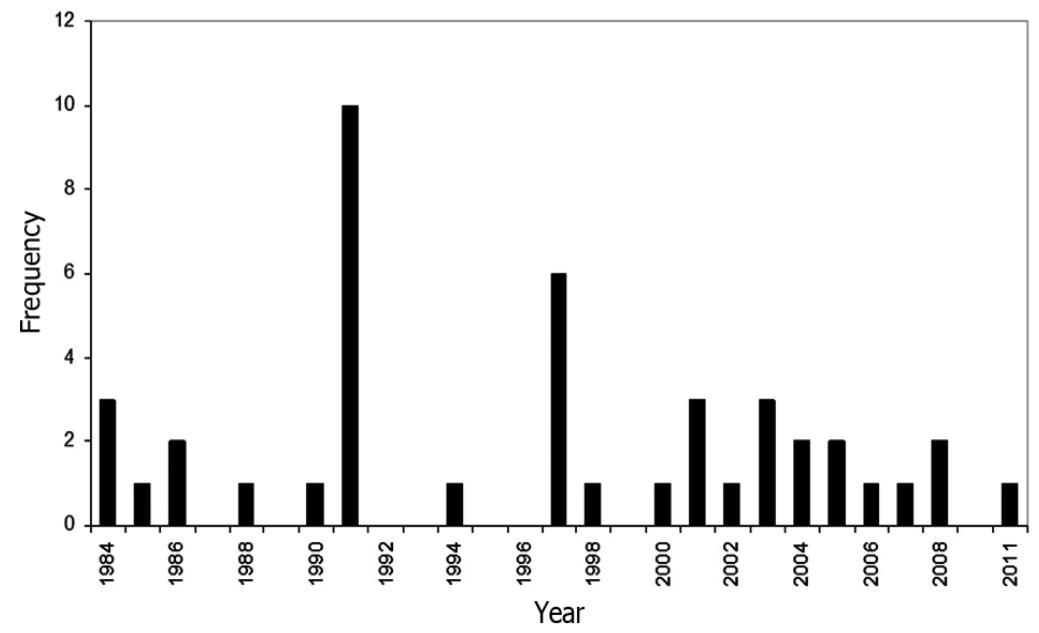

in 1991 (Fig. 3). The month of long-finned pilot whale stranding was determined for 34 of the 43 dated events. Fifty percent of the strandings occurred during autumn (March-May), 32\% during winter (June-August), 12\% during summer (December to February) and 6\% in spring (September-November). There was insufficient data with a known stranding date to investigate any temporal relationships with oceanographic conditions.

The number of long-finned pilot whales at each stranding event was recorded either exactly or as a close approximate for 59 events. Most events were of pods with between 11 and 100 whales (Fig. 4). The mean of the known sized (or approximately sized) pods was 105 dolphins. The largest pod found stranded in the Falkland (Malvinas) Islands was reported to have between 400 and 500 dolphins.

Figure 3. Annual frequency of long-finned pilot whale strandings in the Falkland (Malvinas) Islands between 1984 and 2011 / Frecuencia anual de varamientos de calderones de aleta larga varados en las islas Falkland (Malvinas) entre 1984 y 2011

Figure 4. Frequency of pod sizes for 59 stranding events of long-finned pilot whales in the Falkland (Malvinas) Islands between 1866 and 2011 / Frecuencia de tamaños grupales para 59 varamientos de calderones de aleta larga en las islas Fakland (Malvinas) entre los años 1866 y 2011

${ }^{3}$ British Museum of Natural History, London

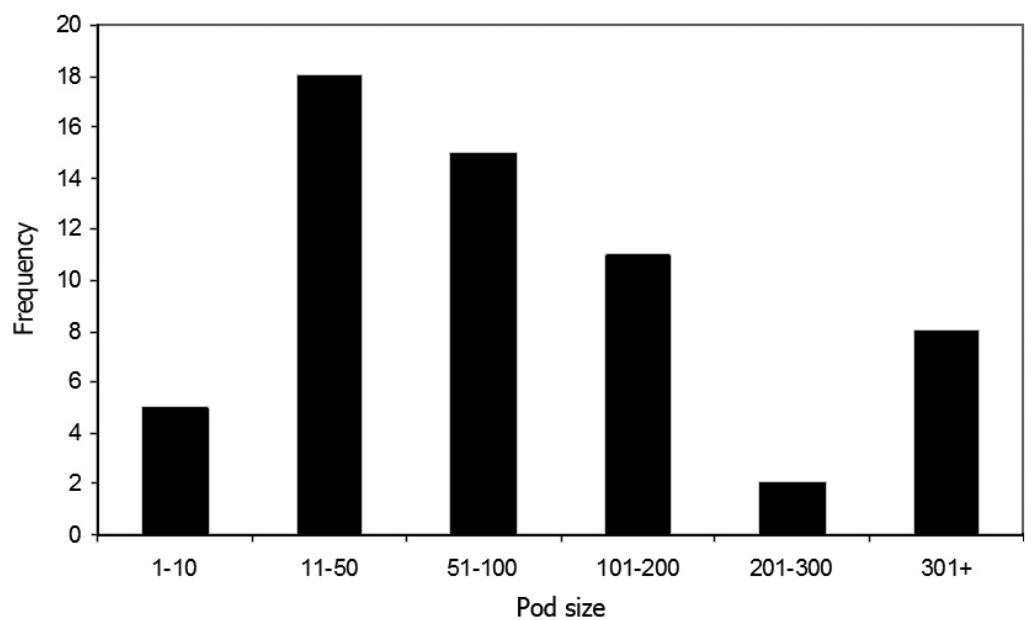


Two hourglass dolphins were reported stranded in the Falkland (Malvinas) Islands, one in December 1981 at New Island, which is within $30 \mathrm{~km}$ of the shelf break and another in January 2004 in the southeastern sector of the archipelago (Table 1). There was one record of a stranded southern right whale dolphin from the 1940s/1950s in the eastern sector of the archipelago and one at Sea Lion Island in February 2004, which was returned successfully to the sea. There were 3 records of stranded bottlenose dolphin for the Falkland (Malvinas) Islands, all at locations on the Patagonian Shelf. Two males were found with a pod of 200 stranded long-finned pilot whales in May 1984 (Strange 1992), a single bottlenose dolphin was found in December 1992 and another one was found washed ashore together with a leopard seal (Hydrurga leptonyx Blainville, 1820) in October 1996.

There were 9 records of Commerson's dolphin stranded in the Falkland (Malvinas) Islands and 7 records of stranded Peale's dolphin (Table 1). Most records for both species are specimens collected during 1923-1952 and deposited at BMNH with no specific location information (Hamilton 1952), but there are also some current records. Only one stranding record for the 2 species was at an island located within $30 \mathrm{~km}$ of the shelf break. J. Hamilton reported 4 dusky dolphin strandings during the 1950s but with no specific location information (van Waerebeek et al. 1995) and one specimen found stranded alive in May 2008 was taken from the shallow bay where it stranded and released into open deep water (Table 1).

\section{Porpoises}

There were 4 documented stranding records of spectacled porpoise for the Falkland (Malvinas) Islands - a complete skeleton of a sub-adult or adult in 1939, a stranding record reported in 1952, a weathered skull was found in 2008 and a complete skeleton of an adult male was found in March 2011. The 2 recent strandings occurred on coastlines on the Patagonian Shelf, whilst there was no location information for the other 2 records (Table 1 ).

\section{Discussion}

It is important when interpreting stranding records to consider that carcasses of coastal and nearshore cetacean species are more likely to end up ashore because pelagic species may not seek sheltered areas when in distress. As well, smaller species may be less at risk of becoming stuck in low tides, whilst larger species may tend to break apart or sink rather than wash up on a coastline. Stranding records may also be biased by mortality events, social behaviour and propensity to strand. It also needs to be noted that the stranding record for the Falkland (Malvinas) Islands is not based on any systematic or periodic searches for stranded cetaceans, as occurs for example in Tierra del Fuego (Goodall et al. 2008a).

The many islands in the archipelago differ in their distance from the continental shelf, protection from the prevailing northerly flowing current and westerly winds, and influence of local currents. These factors combine to create specific pelagic and nearshore marine habitats in different parts of the archipelago, which influence not only what cetacean species may be present, but whether dead or live stranded cetaceans remain ashore or get refloated. The analysis of where stranded cetaceans were found in the Falklands (Malvinas) archipelago indicated that most records were from islands on the Patagonian Shelf and in the lee of the prevailing current, which are by nature more likely to have depositional coastlines. Therefore, this result may reflect the higher likelihood of a dead or live stranded cetacean remaining ashore on islands in this sector of the archipelago rather than a species having a preference for this type of marine habitat.

For these reasons, some caution should be given to the dataset. However, despite these issues, the importance of the stranding record is that the collection of data of stranding events over many decades may reveal changes in cetacean distribution due to varying oceanographic conditions or anthropogenic threats in a way that short-term surveys cannot.

\section{SPECIES ACCOUNTS}

\section{BaLEen WHALES}

The large baleen whales - blue whale, sei whale and fin whale - have worldwide distributions and are reported to occur and/or have occurred in the southwest South Atlantic Ocean (White et al. 2002, Goodall et al. 2008b). From the early 1900s, all 3 species were hunted extensively. For whaling expeditions based out of New Island during 1912-1914, more than half of the 266 whales caught were sei whale, $37 \%$ were fin whale and only 3 blue whales were captured (White et al. 2002).

Based on sighting data and recaptures of marked individuals, Branch et al. (2007) concluded that the blue whale is extremely rare in the southwestern South Atlantic, despite there being areas of high chlorophyll- $a$ 
concentrations, perhaps because the Patagonian Shelf is shallower than the depths preferred by the species. This is confirmed by a lack of blue whale sightings during the 3 years at-sea survey (White et al. 2002) and no recorded strandings of blue whale in Tierra del Fuego (Goodall et al. 2008b). Whilst the blue whale may have been present in the Falkland (Malvinas) Islands during the early 1900s and perhaps occasionally during the mid-part of the $20^{\text {th }}$ century, there have not been any recent records.

Comparatively, sei and fin whale are considered as scarce in the waters of the Falkland (Malvinas) Islands (White et al. 2002). This scarce or infrequent presence is supported by the stranding record with 23 large baleen whale strandings. White et al. (2002) also reported that sei whales were mostly found in shallow rather than deep water $(<1,000 \mathrm{~m})$ and that fin whales were seen throughout the waters around the Falklands (Malvinas). The stranding record also supports a preference for Patagonian Shelf waters.

The seasonal presence of sei and fin whale detected by at-sea surveys is also supported by the stranding record. The 8 large baleen whale strandings during 2000 to 2009 all occurred during January to May, in line with 93\% of fin whales sighted during November and January and the number of sei whales recorded increasing in November and remaining high until April (White et al. 2002).

Iñiguez et al. (2010) collated recent sightings of sei whale in the southwest South Atlantic Ocean and they suggested that although the data indicated a slow recovery in the region, given the notably erratic unpredictability in the occurrence of this species, they could not rule out the possibility that their sightings represent a temporary distributional shift from elsewhere. The recent increase in sightings in the region reported by Iñiguez et al. (2010) is also supported by the increased number of strandings in the Falkland (Malvinas) Islands in the last decade.

Southern right whale and humpback whale are reported as rare in the Falkland (Malvinas) Islands (White et al. 2002) and this is supported by the stranding record. Although southern right whale has been recorded in recent years in the area nearby the eastern entrance of the Magellan Strait, with an apparent increasing number of sightings since the 1990s (Belgrano et al. 2008), there have been few strandings recorded in Tierra del Fuego (Goodall et al. 2008a). Humpback whales are also rarely seen in southern Argentinean waters (Crespo et al. 2008).
A number of small baleen whale species that are difficult to identify at sea and also possibly if stranded ashore are found in the sub-Antarctic zone, including dwarf minke whale (Balaenoptera acutorostrata subspecies), Antarctic minke whale (B. bonaerensis Burmeister, 1867) and pygmy right whale. The Falklands (Malvinas) 3 years at-sea survey data and the stranding record did not identify minke whale records to species level. Both species are reported in the stranding record for Tierra del Fuego in equal numbers (Goodall et al. 2008b). The few records (4) of minke whale stranded in the Falkland (Malvinas) Islands, all since 1992, support the infrequent presence concluded from at-sea sightings for this area (White et al. 2002).

Pygmy right whale was recorded stranded only once in the Falkland (Malvinas) Islands (Hamilton 1952) and has not been recorded during at-sea surveys (White et al. 2002, McCarthy \& Unwin 2007, Munro 2011). As one pygmy right whale was found stranded in Tierra del Fuego and another was found on an adjacent small island (Aguayo-Lobo et al. 2008, Goodall et al. 2008b), the species may well be a very occasional visitor to the southwestern South Atlantic region.

\section{SPERM WHALE}

Sperm whale is found worldwide, with mature males migrating from feeding grounds at high latitudes at the end of the summer to tropical waters, whereas females tend not to venture below $40^{\circ} \mathrm{S}$ (Reeves et al. 2002). This is supported by the stranding records for both Tierra del Fuego (Pimper et al. 2008) and the Falkland (Malvinas) Islands (this study). In the southwest South Atlantic region, the majority of both at-sea surveys and strandings were of single individuals, and the largest pod stranding was of 10 male whales in Tierra del Fuego and of 18 male whales in the Falkland (Malvinas) Islands. White et al. (2002) reported that the sperm whale was scarce in the Falkland (Malvinas) Islands. However, the stranding record and additional sighting records (Yates \& Brickle 2007, this study), suggest a higher abundance, both in historical times and currently. Although at-sea sightings of sperm whales are focused in the far north and south waters of the Falkland (Malvinas) Islands at around 1,000 $\mathrm{m}$ (White et al. 2002), more than half of the sperm whale strandings occurred on coastlines on the Patagonian Shelf, possibly suggesting some use of shallower marine habitats. 


\section{Beaked WHALES}

MacLeod \& Mitchell (2006) identified the Falkland (Malvinas) Islands and Tierra del Fuego as one of the world's key areas for beaked whales. The publication of further records by Otley et al. (2011) and this study confirms this assessment. Of the 10 most common cetacean species to strand in the Falkland (Malvinas) Islands, 4 are beaked whales: strap-toothed whale, southern bottlenose whale, Arnoux's beaked whale and Cuvier's beaked whale. Three years of at-sea surveys around the waters of the Falkland (Malvinas) Islands yielded 18 sightings of southern bottlenose whale, 6 unidentified Mesoplodon sp. beaked whale and one sighting of a Gray's beaked whale, giving a status of scarce for southern bottlenose whale and rare for Mesoplodon species (White et al. 2002). However, the stranding data would suggest that beaked whales have a more frequent occurrence than indicated by at-sea sightings, particularly for strap-toothed whale. The only beaked whale species known to occur in the southwest South Atlantic Ocean but not yet reported from the Falkland (Malvinas) Islands is Shepherd's beaked whale (Tasmacetus shepherdi Oliver, 1937) (Otley et al. 2011).

Little is known about the preferred marine habitats of most beaked whale species. White et al. (2002) sighted beaked whales only to the east of the Falkland (Mavinas) Islands in water deeper than 1,000 m. However, most strandings, including of young animals, occurred on coastlines on Patagonian Shelf waters, suggesting that beaked whales do use shallower waters.

\section{DoLPHINS}

The killer whale is currently identified as a single species, although genetic analysis combined with morphological and behavioural differences indicates that 3 species should be recognised (Morin et al. 2010). A fourth ecotype has also recently been identified (Pitman et al. 2010). In the Falkland (Malvinas) Islands, the 3 year atsea surveys indicated that the killer whale is a scarce species with only 7 records, being in coastal and Patagonian Shelf waters, alone or in pods of up to 6 animals (White et al. 2002). However, both in the Falkland (Malvinas) Islands and along the Argentinean coastline, at a few sites adjacent to pinniped breeding colonies, killer whales are seen almost daily during the pup rearing period, e.g., Sea Lion Island where southern elephant seals (Mirounga leonine) breed (Yates et al. 2007, Crespo et al. 2008). Additionally, killer whales are infrequently sighted close to toothfish longline fishing vessels working in the Falkland (Malvinas) Islands (Yates \& Brickle 2007). Despite a regular (perhaps seasonal) presence in some coastal areas, the stranding record, with only 4 individuals, supports the assessment of scarce or infrequent by White et al. (2002).

The killer whale is also seen infrequently around the most southern parts of the South American mainland (Aguayo-Lobo et al. 2008, Goodall et al. 2008a). These records as well as the stranding record in the Falkland (Malvinas) Islands do not identify killer whale to an identifiable species/ecotype. In the Falkland (Malvinas) Islands, a study over 2 years of 6-12 killer whales at Sea Lion Island recorded the animals as Type A (Yates et al. 2007), which has a circumpolar distribution and is migratory. A group photographed in February 1979 to the north of the islands was identified as Type B, which is known almost entirely from Antarctic waters but could also be migratory (Pitman \& Ensor 2003).

Type D killer whale, known only from one stranding and 6 at-sea records, are not recorded in the Falkland (Malvinas) Islands, although all the records are from between $40-60^{\circ} \mathrm{S}$ (Pitman et al. 2010). All 3 Type D killer whales sighted in the South Atlantic sector of the Southern Ocean have been sighted in deep, oceanic water, which in the Falkland (Malvinas) Islands has much reduced sighting effort compared to shelf and coastal waters (e.g., White et al. 2002).

The long-finned pilot whale has a circumpolar distribution in the Southern Hemisphere between $20^{\circ}$ to $60^{\circ}$ latitude. The species is described by White et al. (2002) as being regularly seen in the Falkland (Malvinas) Islands and this is confirmed by the stranding record, with it being the most frequently stranded species. Although the long-finned pilot whale was sighted throughout the year, the 3 years of at-sea surveys suggested a higher frequency of sightings during winter months and this is also supported by the stranding record, with $80 \%$ of the strandings occurring during autumn and winter.

The Falkland (Malvinas) Islands at-sea sighting data indicates that long-finned pilot whales generally prefer waters deeper than $200 \mathrm{~m}$, with the only records in water less than $200 \mathrm{~m}$ deep being to the east of the archipelago (White et al. 2002). However, three quarters of the stranding records were on coastlines on the Patagonian Shelf, indicating that the species appears to forage in or pass through shallower areas. 
The mean size for long-finned pilot whales found stranded or herded ashore in the Faroe Islands, Newfoundland and Tasmania are reported to be around 80-110 individuals (Kasuya et al. 1987, Bloch et al. 1993, Bannister et al. 1996), which is similar to the mean reported stranded pod size for the Falkland (Malvinas) Islands. Comparatively, in Argentina, the stranding record for a similar period to that for this study reports fewer strandings (15 stranding events) and smaller pods ( 1 and 56 whales and one pod of 400+ whales in 1991) (García 2007, Goodall et al. 2008a). There were 12 strandings of large (200+ individuals) pods of pilot whale in the Falkland (Malvinas) Islands, but such large pod strandings have also been reported in Tasmania and New Zealand (Nicol \& Croome 1988, Bannister et al. 1996, respectively). Although pods of long-finned pilot whale were observed in Falkland Island waters in association with southern right whale dolphin and hourglass dolphin (White et al. 2002), the one mixed species assemblage stranded pod had 200 long-finned pilot whales and 2 male bottlenose dolphins.

The hourglass dolphin and the southern right whale dolphin have circumpolar distributions in offshore waters between $45^{\circ}$ and $60^{\circ} \mathrm{S}$ (Reeves et al. 2002). In the Falkland (Malvinas) Islands waters, the hourglass dolphin is a commonly sighted species in waters deeper than $200 \mathrm{~m}$, particularly during September to March (White et al. 2002). Despite being common in the waters around the Falkland (Malvinas) Islands, because the hourglass dolphin is an offshore species, there is probably a low likelihood of sick and dead animals ending up on coastlines. Yet the 2 stranding records do support the species preferred marine habitat and seasonality as indicated by at-sea sightings. In contrast, the southern right whale dolphin was rarely sighted in the Falkland (Malvinas) Islands during 3 years of at-sea surveys, with 5 records of pods of 6, 20, 60 and 120 animals amongst pods of long-finned pilot whale in deep waters to the east of the Falkland (Malvinas) Islands (White et al. 2002). This rare state and preference of eastern deep waters is also supported by the stranding record.

The common bottlenose dolphin is a cosmopolitan species that until recently was not documented to range to latitudes greater than $45^{\circ}$ in either hemisphere, with a few exceptions. However, in recent years, there have been sightings in continental South American waters as far south as $55^{\circ} \mathrm{S}$ (southern coast of Tierra del Fuego), although it is unclear if the new records are recent colonisations or the result of increased survey effort in those areas (Goodall et al. 2010, Olavarria et al. 2010). These authors consider that the species has an infrequent presence south of $45^{\circ} \mathrm{S}$ in South America and this is also supported by the lack of at-sea sightings and only 4 stranded records for the Falkland (Malvinas) Islands (White et al. 2002 and this study, respectively).

There are 2 subspecies of Commerson's dolphin, one in southern South America and the other at Ile Kerguelen, which are separated by $8,500 \mathrm{~km}$ (Robineau et al. 2007). In South America, the Commerson's dolphin ranges from $30^{\circ} \mathrm{S}$ down to South Shetland Islands $\left(61^{\circ} \mathrm{S}\right)$ and Falkland (Malvinas) Islands (Reeves et al. 2002). The 3 years of atsea surveys around the Falkland (Malvinas) Islands showed that the species is the most frequently recorded cetacean encountered. Commerson's dolphin occurred only within $10 \mathrm{~km}$ of the coast, whilst Peale's dolphin, which is distributed from $38^{\circ} \mathrm{S}$ on the Pacific coast and $33^{\circ} \mathrm{S}$ on the Atlantic coast south to the Drake Passage (Culik 2010a), has a continuous distribution from the Falkland (Malvinas) Islands to mainland South America (Gillon et al. 2000). This distribution is also supported by the stranding record, with most strandings occurring on coastlines in continental shelf waters.

The low frequency of strandings of Peale's dolphin and Commerson's dolphin compared to the at-sea surveys may reflect a number of factors - the ability of small cetaceans to avoid getting trapped in shallow waters, their low mass may mean carcasses are dragged out by outgoing tides, their small size means low numbers of birds attending stranded specimens (which is often how people find them) and that the smaller skeleton material is harder to find.

The dusky dolphin is widespread in the Southern Hemisphere but with a probable discontinuous distribution in the coastal temperate waters off Australia, New Zealand, South America and Southern Africa and oceanic islands (Culik 2010b). The species is common in the northern range of the Patagonian Shelf, but only occasionally reaches Tierra del Fuego (Goodall et al. 1997a, b, Crespo et al. 2008). Their abundance on the Patagonian Shelf appears to match the distribution of their preferred prey - the Argentine anchovy (Engraulis anchoita) (Garaffo et al. 2011).

Dusky dolphin was not reported during 3 years of atsea surveys in the waters surrounding the Falkland (Malvinas) Islands (White et al. 2002) or during daily observations off a seismic survey vessel working in an area centred 100 nautical miles to the north of the Falkland 
(Malvinas) Islands during December 2010 to April 2011 (Munro 2011). However, during other at-sea surveys of shorter duration, they were sighted twice in deep oceanic waters to the north and east of the islands (A. Black pers. comm. ${ }^{4}$ ) and a group of 12 dusky dolphins were seen in a mixed species assemblage pod containing many longfinned pilot whales and a few hourglass dolphins in an area to the east of the islands in waters $488 \mathrm{~m}$ deep (McCarthy \& Unwin 2007). Goodall et al. (1997b) also documents 8 sightings for the Falkland (Malvinas) Islands, with 6 of the sightings being in offshore waters to the northeast. Based on these sightings and the 4 stranding records, with 3 specimens having been collected in the 1950s, the species should be considered a rare visitor in the offshore waters of the Falkland (Malvinas) Islands but further more intensive surveys in the northern parts of the Islands may reveal a more frequent occurrence.

There is no at-sea or stranding record in Falkland (Malvinas) Islands for 4 species of dolphin that have been reported at the southern extent of the South American continent - long-beaked common dolphin (Delphinus delphinus Gray, 1828), false killer whale (Pseudorca crassidens Owen, 1846), Chilean dolphin (C. eutropia Gray, 1846) and Risso's dolphin (Grampus griseus G. Cuvier, 1812). The single specimen of longbeaked common dolphin found in Tierra del Fuego is considered to be an extraterritorial stray from warmer climates (Goodall et al. 20055). False killer whale, though recorded stranded in Tierra del Fuego, is not considered to be a regular visitor to the southwest South Atlantic region (Goodall et al. 2008a) and this is supported by the lack of any records in the Falkland (Malvinas) Islands. The Chilean dolphin is a coastal South American dolphin, found almost entirely on the Pacific coastline around to the southern coast of Tierra del Fuego (Reeves et al. 2002, Goodall et al. 2008a). The Chilean dolphin's preference for shallower waters is likely to have prevented it from crossing the Patagonian shelf waters to the coastal waters of the Falkland (Malvinas) Islands.

Risso's dolphin has been found stranded in Tierra del Fuego (23 stranding events) and seen at sea along the Patagonian Shelf south to $55^{\circ} \mathrm{S}$ and also in the Magellan Strait (Olavarria et al. 2001, Crespo et al. 2008, Goodall et al. 2008a). This pelagic species is often found near to subsurface seamounts and escarpments (Culik 2010c), features that occur in the waters around the Falkland (Malvinas) Islands. There are no documented sightings or strandings of Risso's dolphin in the Falkland (Malvinas) Islands, despite being described as occurring there (Reeves et al. 2002). It may be that the species has not been recorded in the Falkland (Malvinas) Islands because it is preferred deeper waters are less often surveyed and are far from land, so that dead specimens are not likely to reach the shores of the Falkland (Malvinas) Islands.

\section{Porpoises}

The spectacled porpoise has been sighted and found stranded on the continents and islands circumpolar between $40^{\circ}$ and $50^{\circ} \mathrm{S}$. Strandings and sightings are rare, except for strandings in Tierra del Fuego, perhaps as a reflection of high bycatch rates in coastal gillnet fisheries (Goodall et al. 2008a). The species apparent rareness may be related to its diet, which as revealed by stable isotope analysis indicates offshore foraging in the oceanic waters (Riccialdelli et al. 2010).

There are 4 documented records for spectacled porpoise for the Falkland (Malvinas) Islands, from 1939 to 2011. Only one of the stranding records could be dated - being March. The spectacled porpoise was not seen during 3 years of dedicated at-sea surveys around the Falkland (Malvinas) Islands (White et al. 2002) or during 2 years of surveys in the waters between the Falkland (Malvinas) Islands and South Georgia (Black 2005). However, there was one live sighting during a dedicated cetacean observation period from December 2006 to May 2007 on a seismic survey vessel (McCarthy \& Unwin 2007). The spectacled porpoise was seen in January in waters to the east of the Falkland (Malvinas) Islands at 1,284 m water depth. Even with the 3 new records of spectacled porpoise for the Falkland (Malvinas) Islands, all occurring during 2007-2011, the species should be considered as a rare species within the Falkland (Malvinas) Islands cetacean community. It may be that the species is not likely to be found stranded or seen at sea because its preferred deeper water is not often surveyed and is far from land, so that dead specimens are not likely to reach the shores of the Falkland (Malvinas) Islands.

${ }^{4}$ South Georgia Government, Stanley

${ }^{5}$ Goodall RNP, CC Boy, LE Pimper \& SM Macnie. 2005. Range extensions and exceptional records of cetaceans for Tierra del Fuego. In: $16^{\text {th }}$ Biennial Conference on the Biology of Marine Mammals, San Diego 
Burmeister's porpoise (Phocoena spinipinnis Burmeister, 1865) is a coastal South American porpoise, found along both the Pacific and Atlantic coastlines (Reeves et al. 2002, Goodall et al. 2008a). There is no atsea or stranding record in the Falkland (Malvinas) Islands. Whilst its distribution might suggest it could also include the Falkland (Malvinas) Islands, the species preference for shallower waters is likely to have excluded it from crossing the Patagonian shelf waters to the coastal waters of the Falkland (Malvinas) Islands. However, it is unclear why Commerson's dolphin, a coastal species that does not have an evident continuous distribution across the Patagonian Shelf, become established in the Falkland (Malvinas) Islands (and also at Ile Kerguelen), whereas Burmeister's porpoise has not.

\section{FaLKLAND (MaLVINAS) IsLANDS CETACEAN COMMUNITY}

The Falkland (Malvinas) Islands cetacean community consists of 24 species (Table 2). The species composition is similar to that reported in the southern waters of Argentina and Chile (Aguayo-Lobo et al. 2008, Crespo et al. 2008, Goodall et al. 2008 a, b, Pimper et al. 2008, Goodall et al. 2010, Olavarría et al. 2010). However, there are 4 species of dolphin and one coastal porpoise species found in southern continental South American waters that are not found in the Falkland (Malvinas) Islands. Perhaps some of these additional species (e.g., Risso's dolphin and false killer whale) have been reported on the continent due to the longer and more investigative nature of the stranding record held for that region. Previous descriptions of the Falkland (Malvinas) Islands cetacean community have been based on at-sea sighting surveys, ad hoc sightings and some documented strandings. The stranding record presented here in general supports the described cetacean community. No species sighted at sea were not found stranded ashore. Pygmy right whale, bottlenose dolphin and all the beaked whale species except Gray's beaked whale and southern bottlenose whale were only documented in the stranding record.

In more detail, the stranding record showed that 7 species of beaked whale are probably more abundant than at-sea sightings would suggest. Together with the observations of Yates \& Brickle (2007), the stranding record also showed that the sperm whale and the killer whale are also more abundant in the Falkland (Malvinas) Islands than previously described. Using abundance scale employed for the at-sea sightings (White et al. 2002) together with the stranding record and sighting data published since 2002, the sperm whale is considered to have a regular presence and the killer whale is considered to have an infrequent presence. The strap-toothed whale has been upgraded from a rare to an infrequent presence. The dusky dolphin and spectacled porpoise have been ranked as rare given the few stranding records and the handful of ad hoc at-sea sightings, and the bottlenose dolphin has also been assigned a rare status given the few stranding records.

Five species are considered regular, 6 are considered infrequent and 11 species are considered rare (Table 2). The blue whale and the pygmy right whale may have been present historically in the Falkland (Malvinas) Islands but there are no recent records. Of the species found in the Falkland (Malvinas) Islands, southern Argentina and southern Chile, all species have a similar level of presence across the 3 areas (Aguayo-Lobo et al. 2008, Crespo et al. 2008).

Table 2. The frequency of presence of $\mathbf{2 4}$ cetacean species in the Falkland (Malvinas) Islands based on at-sea sighting data and stranding records between 1866 and 2012 / Frecuencia de la presencia de 24 especies cetáceos alrededor de las islas Falkland (Malvinas) basada en avistamientos y varamientos registrados entre 1866 y 2012

\begin{tabular}{ll}
\hline Species & Presence \\
\hline Commerson's dolphin & Regular \\
Hourglass dolphin & Regular \\
Long-finned pilot whale & Regular \\
Peale's dolphin & Regular \\
Sperm whale & Regular \\
Fin whale & Infrequent \\
Killer whale & Infrequent \\
Minke whale & Infrequent \\
Sei whale & Infrequent \\
Southern bottlenose whale & Infrequent \\
Strap-toothed whale & Infrequent \\
Andrew's beaked whale & Rare \\
Arnoux's beaked whale & Rare \\
Bottlenose dolphin & Rare \\
Cuvier's beaked whale & Rare \\
Dusky dolphin & Rare \\
Gray's beaked whale & Rare \\
Hector's beaked whale & Rare \\
Humpback whale & Rare \\
Southern right whale & Rare \\
Southern right whale dolphin & Rare \\
Spectacled porpoise & Rare \\
Blue whale & Present historically, no current records \\
Pygmy right whale & Present historically, no current records \\
\hline & \\
\hline
\end{tabular}


The stranding record for the Falkland (Malvinas) Islands supports the at-sea documented seasonal presence of some species, such as an increase of sei whale and fin whale during January to May and of long-finned pilot whale during autumn and winter. The stranding record also suggests some potential temporal changes in range. Two frequently stranded species - long-finned pilot whale and strap-toothed whale - were found stranded throughout the period 1875 to 2012. In comparison, Arnoux's beaked whale stranded only between 1931 and 1965, Gray's beaked whale was not recorded until 1981, Andrew's beaked whale was not recorded until 1987, minke whale was not recorded until 1992 and the number of large baleen whales has increased since 1990. Some of the beaked whale species may simply not be particularly common. However, for some of the more frequent species, recovery from over-exploitation and/or changes in water temperature and/or prey availability may well be influencing their distribution and abundance. There was insufficient data with a known stranding date to investigate any temporal relationships with oceanographic conditions.

Continuing the Falkland (Malvinas) Islands stranding record but following a stranding response plan and collating the stranding data in a central database should allow further temporal changes to be detected and elucidated. This task is a priority action in the 'Falkland Islands Species Action Plan for Cetaceans 2008-2018', and the plan details what data and samples should be collected (Falkland Islands Government 2008).

This first presentation of the Falkland (Malvinas) Islands cetacean community based on at-sea and stranding records fills a knowledge gap for the southwest Atlantic Ocean. It has been recognized that the Falkland (Malvinas) Islands is a key area for some species (e.g., beaked whales, MacLeod \& Mitchell 2006), as well for some baleen whale species that appear to be increasing in number after a history of over-exploitation. The lack of stranded animals in the Falkland (Malvinas) Islands showing obvious signs of injury indicates that compared to other regions of southern South America where dolphins drown in gill nets (Goodall et al. 2008a), there are fewer threats to cetaceans in the area. However, the acoustic noise of naval ships, seismic survey ships and oil exploration drilling rigs, and the plans for oil extraction in the near future still remain areas of concern.

\section{Acknowledgments}

I thank all the discoverers and investigators of dolphin and whale strandings in the Falkland Islands for their enthusiasm and dedication to recording the natural history of the islands. The help of John Smith, Richard White, Natalie Goodall, Lida Pimper, Enrique Crespo, Anton van Helden and Carlos Olavarría to confirm specimen identification was gratefully appreciated. Thanks also to Michael Unwin for discussing his sighting of a spectacled porpoise with me. Dave Janiger's prompt delivery of required references was very much appreciated. Carlos Olavarría provided a helpful assessment of an earlier draft as well as providing the Spanish translation. Many thanks to two anonymous referees and the editor who helped to improve the manuscript.

\section{LITERATURE CITED}

Aguayo-Lobo A, D Torres \& J Acevedo. 1998. Los mamíferos marinos de Chile: I. Cetacea. Series Científica INACH 48: 19-159.

Aragones LV, MAA Roque, MB Flores, RP Encomienda, GE Laule, BG Espinos, FE Maniago, GC Diaz, EB Alesna \& RC Braun. 2010. The Philippine marine mammal strandings from 1998 to 2009: animals in the Philippines in peril? Aquatic Mammals 36: 219-233.

Baker AN. 2001. Status, relationships and distribution of Mesoplodon bowdoini Andrews, 1908 (Cetacea: Ziphiidae). Marine Mammal Science 17: 473-493.

Bannister JL, CM Kemper \& RM Warneke. 1996. The action plan for Australian cetaceans, 272 pp. Environment Australia, Camberra.

Bastida R, D Rodríguez, E Secchi \& V da Silva. 2007. Mamíferos acuáticos de Sudamérica y Antártida, 366 pp. Vázquez Mazzini Editores, Buenos Aires.

Belgrano J, M Iñíguez, J Gibbons, C García \& C Olavarría. 2008. South-west Atlantic right whales Eubalaena australis (Desmoulins, 1822) distribution nearby the Magellan Strait. Anales del Instituto de la Patagonia, Chile 36: 69-74.

Black AD. 2005. Seabird and marine mammal distribution in the waters around South Georgia, 2002-2004, 163 pp. A Report to South Georgia Government, Stanley, Falklands Islands.

Bloch D, G Desportes, R Mouritsen, A Skaaning \& E Stefansson. 1993. An introduction to studies of the ecology and status of the long-finned pilot whale (Globicephala melas) off the Faroe Islands, 1986-1988. Report of the International Whaling Commission Special Issue 14: 1-32.

Branch TA, KM Stafford, DM Palacios, C Allison, JL Bannister, CLK Burton, E Cabrera, CA Carlson, B Galletti-Vernazzani, PC Gill, R Hucke-Gaete, KCS Jenner, M-NM Jenner, K Matsuoka, YA Mikhalev, T Miyashita, MG Morrice, S Nishiwaki, VJ Sturrock, D 
Tormosov, RC Anderson, AN Baker, PB Best, P Borsa, RL Brownell, S Childerhouse, KP Findlay, T Gerrodetter, J Ilangakoon, M Joergensen, B Kahn, DK Ljundblad, B Maughan, RD McCauley, S McKay, TF Norris, Oman Whale and Dolphin Research Group, S Rankin, F Samaran, D Thiele, K Van Waerebeek \& RM Warneke. 2007. Past and present distribution, densities and movements of blue whales Balaenoptera musculus in the Southern Hemisphere and northern Indian Ocean. Mammal Review 37: 116-175.

Brown SG. 1978. Sei whale marking data. Report of the International Whaling Commission 28: 369-372.

Crespo EA, NA García, SL Dans \& SN Pedraza. 2008. Mamíferos marinos, Tursiops truncates, Grampus griseus. Otros delfines (southern right dolphin), Phocoena dioptrica, Lagenorhynchus cruciger, Pseudorca crassidens, Lagenorhynchus australis, Cephalorhynchus commersonii and Rorcuales In: Boltovskoy D (ed). Atlas de sensibilidad ambiental del la costa y el Mar Argentino. Secretaría de Ambiente y Desarrollo Sustentable de la Nación. [on line] $<$ http://atlas.ambiente.gov.ar/index.htm>

Culik B. 2010a. Odontocetes. The toothed whales: 'Grampus griseus'. UNEP/CMS Secretariat, Bonn [on line] <http:// www.cms.int/reports/small_cetaceans/index.htm>

Culik B. 2010b. Odontocetes. The toothed whales: 'Lagenorhynchus australis'. UNEP/CMS Secretariat, Bonn. [on line] <http://www.cms.int/reports/small_cetaceans/ index.htm>

Culik B. 2010c. Odontocetes. The toothed whales: 'Lagenorhynchus obscurus'. UNEP/CMS Secretariat, Bonn. [on line] <http://www.cms.int/reports/small_cetaceans/ index.htm>

Danil K, SJ Chivers, MD Henshaw, JL Thieleking, R Daniels \& JA St Leger. 2010. Cetacean strandings in San Diego County, California, USA: 1851-2008. Journal of Cetacean Research and Management 11: 163-184.

Falkland Islands Government. 2008. Falkland Islands species action plan for cetaceans 2008-2018, 34 pp. Environmental Planning Department, Stanley.

Fraser FC. 1950. Note on a skull of Hector's beaked whale Mesoplodon hectori from the Falkland Islands. Proceedings of the Linnean Society of London 162: 5-52.

Garaffo GV, SL Dans, SN Pedraza, M Degrati, A Schiavini, R Gonzalez \& EA Crespo. 2011. Modelling habitat use for dusky dolphin and Commerson's dolphin in Patagonia. Marine Ecology Progress Series 421: 217-227.

García MF. 2007. Estructura de edades de manadas del delfín piloto (Globicephala melas) (Cetacea, Delphinidae) varadas en la costa de Patagonia, Argentina. Seminario de Licenciatura en Ciencias Biológicas, Universidad Nacional de la Patagonia San Juan Bosco, Puerto Madryn, 99 pp.

Gillon KW, RW White \& AD Black. 2000. Seabird and marine mammal surveys between Stanley, Falkland Islands, and Punta Arenas, Chile, 1999-2000. A JNCC report to the Falkland Islands Government and Falklands Conservation, 23 pp. Joint Nature Conservation Committee, Peterborough.
Goodall RNP, KS Norris, WE Schevill, F Fraga, R Praderi, MA Iniguez \& JC de Haro. 1997a. Review and update on the biology of Peale's dolphin, Lagenorhynchus australis. Report of the International Whaling Commission 47: 777796.

Goodall RN, JC de Haro, F Fraga, MA Iniguez \& KS Norris. 1997b. Sightings and behaviour of Peale's dolphin, Lagenorhynchus australis, with notes on dusky dolphins, L. obscurus, off southernmost South America. Report of the International Whaling Commission 47: 757-775.

Goodall RNP, N Dellabianca, CC Boy, LG Benegas, LE Pimper \& L Ricciadelli. 2008a. Review of small cetaceans stranded or incidentally captured on the coasts of Tierra del Fuego, Argentina, over 33 years. Paper SC/60/SM21 presented to the International Whaling Commission Scientific Committee, June 2008, 13 pp. [Available from International Whaling Commission Office].

Goodall RNP, LB Benegas, CC Boy \& LE Pimper. 2008b. Baleen whales stranded on the coasts of the Strait of Magellan and Tierra del Fuego, 33 years. Paper SC/60/O11 presented to the International Whaling Commission Scientific Committee, June 20087 pp. [Available from International Whaling Commission Office].

Goodall RNP, MC Marchesi, LE Pimper, N Dellabianca, LG Benegas, MA Torres \& L Riccialdelli. 2010. Southernmost records of bottlenose dolphins, Tursiops truncatus. Polar Biology 34: 1085-1090.

Hamilton JE. 1941. A rare porpoise of the South Atlantic Phocaena dioptrica (Lahille, 1912). Discovery Report 21: 229-234.

Hamilton JE. 1952. Cetacea of the Falkland Islands. Comunicaciones Zoológicas del Museo de Historia Natural de Montevideo 4: 1-6.

Iniguez M, J Masello, C Gribaudo, D Arcucci, F Krohling \& J Belgrano. 2010. On the occurrence of sei whales, Balaenoptera borealis, in the south-western Atlantic. Marine Biodiversity Records 3: 1-6.

Kasuya T, DE Sergeant \& K Tanaka. 1988. Re-examination of life history parameters of long-finned pilot whales in Newfoundland waters. Scientific Reports of the Whales Research Institute, Tokyo 39: 103-119.

MacLeod CD \& G Mitchell. 2006. Key areas for beaked whales worldwide. Journal of Cetacean Research and Management 7: 309-322.

McCarthy PA \& M Unwin. 2007. Seabird and marine mammal observations during 2D seismic survey in South Falklands Basin Survey NO: FOGL06 (N\&S), 115 pp. Report to Falklands Oil and Gas Ltd, RPS Energy, Surrey.

Morin PA, FI Archer, AD Foote, J Vilstrup, EE Allen, $\mathbf{P}$ Wade, J Durban, K Parsons, R Pitman, L Li, P Bouffard, SCA Nielsen, M Rasmussen, E Willerslev, MTP Gilbert \& T Harkins. 2010. Complete mitochondrial genome phylogeographic analysis of killer whales (Orcinus orca) indicates multiple species. Genome Research 20: 908-916. 
Munro G. 2011. Marine mammal and seabird observations during 3D seismic survey in the north Falkland Basin. A Report to Desire Petroleum PLC and Rockhopper Exploration PLC, 88 pp. Stanley, Falkland Islands.

Nicol DJ \& RL Croome. 1988. Trends in the Tasmanian cetacean stranding record. In: Agee ML (ed). Marine mammals of Australasia, field biology and captive management, pp. 59-70. The Royal Zoological Society of New South Wales, Sydney.

Norman SA, CE Bowlby, MS Brancato, J Calambokidis, D Duffield, PJ Gearin, TA Gornall, ME Gosho, B Hanson, J Hodder, SJ Jeffries, B Lagerquist, DM Lambourn, B Mate, B Norberg, RW Osborne, JA Rash, S Riemer \& J Scordino. 2004. Cetacean strandings in Oregon and Washington between 1930 and 2002. Journal of Cetacean Research and Management 6: 87-99.

Olavarría C, AAguayo-Lobo \& R Bernal. 2001. Distribution of Risso’s dolphin (Grampus griseus, Cuvier 1812) in Chilean waters. Revista de Biología Marina y Oceanografía 36: 111-116.

Olavarria C, J Acevedo, HI Vester, J Zamorano-Abramson, FA Viddi, J Gibbons, E Newcombe, J Capella, RA Hoelzel, M Flores, R Hucke-Gaete \& JP Torres-Flórez. 2010. Southernmost distribution of common bottlenose dolphins (Tursiops truncatus) in the eastern South Pacific. Aquatic Mammals 36: 288-293.

Otley H, J Smith \& ML Dalebout. 2011. Beaked whale strandings on the Falkland Islands and South Georgia, South Atlantic Ocean, between 1866 and 2008. Journal of the Marine Biological Association of the United Kingdom 92: 1851-1864.

Palacios DM, SK Salazar \& D Day. 2004. Cetacean remains and strandings in the Galapagos Islands, 1923-2003. Latin America Journal of Aquatic Mammals 3: 127-150.

Pimper LE, RNP Goodall, J Gibbons, AP Sobral, CH Lockyer \& R Praderi. 2008. A review of strandings of sperm whales from the Strait of Magellan to Cape Horn. Paper SC/60/O3 presented to the International Whaling Commission Scientific Committee, June 2008, 8 pp. [Available from International Whaling Commission Office]

Pitman RL \& P Ensor. 2003. Three forms of killer whales (Orcinus orca) in Antarctic waters. Journal of Cetacean Research and Management 5: 131-139.

Pitman RL, JL Durban, M Greenfelder, C Guinet, M Jorgensen, PA Olson, J Plana, P Tixier \& JR Towers. 2010. Observations of a distinctive morphotype of killer whale (Orcinus orca), type D, from subantarctic waters. Polar Biology 34: 303-306.
Pyenson ND. 2010. Carcasses on the coastline: measuring the ecological fidelity of the cetacean stranding record in the eastern North Pacific Ocean. Paleobiology 36: 453-480.

Reeves RR, BS Stewart, PJ Clapham \& JA Powell. 2002. Sea mammals of the world, 527 pp. A \& C Black Publishers, London.

Robineau D, RNP Goodall, F Pichler \& CS Baker. 2007. Description of a new subspecies of Commerson's dolphin, Cephalorhynchus commersonii (Lacépède, 1804), inhabiting the coastal waters of the Kerguelen Islands. Mammalia 71: 172-180.

Riccialdelli L, SD Newsome, ML Fogel \& RNP Goodall. 2010. Isotopic assessment of prey and habitat preferences of a cetacean community in the southwestern South Atlantic Ocean. Marine Ecology Progress Series 418: 235-248.

Strange IJ. 1992. A field guide to the wildlife of the Falkland Islands and South Georgia, 188 pp. Harper and Collins, London.

Turner W. 1880. Report on the bones of cetacean collected during the Voyage of H.M.S. Challenger in the years 18731876. H.M.S. Challenger Reports Zoology 1: 1-45.

Van Waerebeek K. 2002. Pacific white-sided dolphin and dusky dolphin - Lagenorhynchus obliquidens and $L$. obscurus. In: Perrin WF, B Würsig \& JGM Thewissen (eds). Encyclopedia of marine mammals, pp. 859-861. Academic Press, San Diego.

Van Waerebeek K, PJH Van Bree \& PB Best. 1995. On the identity of Prodelphinus petersii Lutken, 1889 and records of dusky dolphin Lagenorhynchus obscurus (Gray, 1828) from the southern Indian and Atlantic Oceans. South African Journal of Marine Science 16: 25-35.

White RW, KW Gillon, AD Black \& JB Reid. 2002. The distribution of seabirds and marine mammals in Falkland Island waters, 107 pp. Joint Nature Conservation Committee, Peterborough.

Woods RW \& A Woods. 2006. Birds and mammals of the Falkland Islands, 192 pp. WILDGuides, London

Yates $\mathbf{O}$ \& $\mathbf{P}$ Brickle. 2007. On the relative abundance and distribution of sperm whales (Physeter macrocephalus) and killer whales (Orcinus orca) in the Falkland Islands longline fishery. Journal of Cetacean Research and Management 9: 65-71.

Yates O, AD Black \& P Palavecino. 2007. Site fidelity and behaviour of killer whales (Orcinus orca). Latin American Journal of Aquatic Mammals 6: 89-95.

Received 9 December 2011 and accepted 15 November 2012

Associate Editor: Maritza Sepúlveda M. 